\title{
Role of Corporate Governance in Determining Dividend Policy: Panel Evidence from India
}

\author{
Debasis Pahi and Inder Sekhar Yadav
}

\begin{abstract}
The present study investigated the nexus between the structure of corporate governance and dividend policy using independent directors and board size as proxy variables for corporate governance for a total of 360 Indian non-financial and non-utility companies included in BSE 500 index during 2012-2016. The study also employed the firm-level control variables such as firm size, beta, profitability, and liquidity to control for firm specific characteristics. Using Tobit and Logit models, the study found that non-executive directors significantly and negatively determined the dividend payout ratio whereas the board size significantly and positively affected the dividend payout ratio of the selected firms. The other firm specific control variables used in the study also had the expected and desired influence on the dividend payout ratio in both the estimated models. Overall, the findings suggest that dividends could be a substitute for corporate governance for monitoring the agency problem.
\end{abstract}

Index Terms-Agency cost, board size, dividends, corporate governance, independent directors.

\section{INTRODUCTION}

Why companies pay dividends is still puzzling the financial economist at large even after six decades of [1] seminal work on dividend policy of firms. Existing theories such as agency, signaling, catering and clientele theory and empirical studies attempted to explain the dividend behavior of firms. However, the attempts made to explain the dividend behavior of firms largely remains inconclusive. One of the most important determinants of dividend behavior is the agency problem [2] which the firms try to mitigate through the structure, composition and conduct of board, which is one of the core elements of corporate governance [3].

In general, board of directors have information about firm's financial policies, so therefore it is posited that they can influence the dividend decision thereby mitigating the agency conflicts between the management and the shareholders [4]-[7]. Additionally, the presence and active participation of independent directors of a firm can influence the propensity to pay dividends thereby protecting the rights of shareholders [8], [9].

Thus, the present study investigates the role of board structure characteristics such as board independence, board size, board meeting, CEO duality and insider's ownership on dividend policy of Indian during 2012-16 for a set of 360 Indian non-financial and non-utility firms included in BSE 500 Index. This study fills the lacuna in the existing literature by focusing on linkage between corporate governance and

Manuscript received March. 1, 2018; revised May 12, 2018.

The authors are with Indian Institute of Technology Kharagpur, India (e-mail: debasis.mcom@gmail.com, yadavis@hss.iitkgp.ac.in). dividend policy in the context of an emerging economy, namely India.

The rest of the paper is sorted as follows. Section II discussed empirical studies related to dividend policy, agency cost and corporate governance. Section III outlines the methodology, and Section IV discussed the observed results. Finally, we talked and presented concluding remarks and limitations in Section V.

\section{RELATED THEORETICAL AND EMPIRICAL STUDIES}

\section{A. Independent/Non-Executive Directors and Dividend Policy}

Mansourinia, E., Emamgholipour, M., Rekabdarkolaei, E.A, and Hozoori, M [10] examined the connection between board independence and dividend payout ratio for Malaysian companies who found no significant impact of board independence on the firm's dividend ratio. Contrary to above findings, [11] who also investigated the role of independent directors on dividend policy for Malaysian firms found that there is a positive and significant influence on dividend payout ratio. However, [12] examining the impact of board independence on the dividend payout ratio for Sri Lankan hotel industry found that there exists an insignificant relationship between board independence and dividend payout ratio. Also [13] found a negligible power of board structure influencing the payout policy for Egyptian firms. Contrary to above studies, [14]-[16] found a significantly positive association of board independence on dividend payout policy. Similarly [17] investigating the impact of qualitative attributes of corporate governance on dividends of 714 Canadian firms found that with a stronger corporate governance mechanism dividends payment tends to be high and board composition influenced dividend payout positively and significantly.

\section{B. Board Size and Dividend Policy}

The usefulness of board can be enhanced by enlarging the firm's board size as it adds different skills and expertise in management which helps in minimizing the agency cost [18]. Similarly, [19] argued for a standardized board size where he claimed that a board size of eight or above eight would more efficiently manage the firm. He contended that a small board might agree on decisions beneficial to them only. However, as the board size increases there might be difference in opinion inside the boardroom which may be beneficial to the shareholders. Keeping this view [20] asserted that a large board with many directors is more valuable than the ones with small board with less number of directors because of their vast knowledge, resources and external links.

Towards this end [10], [15] observed that board size had a 
positive impact on the dividend policy. Similarly [12] noted that board size and dividend payout is positively related but statistically insignificant. Kiel, G.C., Nicholson, G.J [21], Haniffa, R., Hudaib, M [22] found a positive effect of small board size on dividend policy. Contrary to above [23], [24] observed a negative but insignificant association of board size with dividend payout for Malaysian firms

\section{DATA AND METHODOLOGY}

\section{A. Sample and Data}

The companies listed in Bombay Stock Exchange (BSE) 500 index are selected to empirically investigate the nexus between the structure of corporate governance and dividend policy as these companies follow most of the requirements mentioned in Clause 49 of the listing agreement issued by Securities and Exchange Board of India (SEBI) during 2012 to 2016. Prior to 2012, the necessary data on independent directors and board size is not available for Indian firms. During the study period, the data for 460 companies out of 500 companies are available. Out of these 460 companies, this study exclude 75 financial and 22 utility companies as these companies are separately regulated. In addition, this paper exclude three firms' viz., Tata Communication, Indian Hotel Co, and Century Textile since their dividend payout ratio is very high relatively compared with other companies finally leaving about 360 companies for analysis. The necessary required data for the study was collected from Bloomberg database, various annual reports of the respective companies, Centre for Monitoring Indian Economic (CMIE) Prowess IQ database, SEBI, and BSE.

\section{B. Model Specification and Hypothesis}

The present study uses Tobit and Logit regression models due to the nature of the selected data. Tobit model is used because the dependent variable viz., dividend payout ratio (DPR) has values which are zero, more than zero or less than zero. It is worth mentioning that dividend payout ratio may have two outcomes. First, either zero in which case the firms do not distribute dividends and second a positive value in which case the firms declare dividends. Since the dividend payout ratio can never be negative, the left censoring random effect Tobit model is applied. The specification of the model is specified as below:

$$
D P R_{i t}=\left\{\begin{array}{cr}
D P R_{i t}^{*}=\alpha+\beta^{\prime} X_{i t}+\epsilon_{i t} & \text { if } D P R_{i t}>0 \\
=0 & \text { if } D P R_{i t} \leq 0
\end{array}\right\}
$$

where, $D P R^{*}$ it is a latent variable; $X_{i t}$ represent a vector of different independent variables used in the study, and $\epsilon_{i t}$ is a residual error for company ' $i$ ' at year ' $t$ ' with $N\left(0, \sigma^{2}\right)$. Specifically, the Tobit model applied in this study is as follows: (Explained in Section C: Measurement of Variables)

$$
\begin{gathered}
D P R_{i t}^{*}=\alpha+\beta_{1} I N D D I R_{i t}+\beta_{2} B S_{i t}+\beta_{3} R O A_{i t}+ \\
\beta_{4} C R_{i t}+\beta_{5} F T A_{i t}+\beta_{6} S_{Z} E_{i t}+\beta_{7} B E T A_{i t}+ \\
\beta_{8} M T B V_{i t}+\beta_{9} B O R R_{i t}+\beta_{10} I S H_{i t}+\epsilon_{i t}
\end{gathered}
$$

The random effect logit model employed by [12], [25] is also applied here mainly to know the probability of a firm being a dividend payer or non-payer. It is important to note that when a company takes dividend decisions, it may or may not pay dividends. Therefore, it becomes a binary decision. Thus, a Logit model is appropriate and therefore is used. The specification of the Logit regression model is as follows:

$$
P_{i t}=E\left(D I V D U M=\frac{1}{X_{i t}}\right)=\frac{1}{1+\mathrm{e}\left(-X_{i t}^{R} \beta\right)}
$$

where DIVDUM represents the dividend dummy variable, which is equal to 1 if a firm ' $i$ ' is dividend payer in year ' $t$ ' or 0 otherwise. $X_{i t}^{R} \beta$ represents a matrix of unknown parameters to be estimated where $X_{i t}{ }^{R} \beta$ will vary between $-\infty$ to $\infty ; P_{i t}$ range between zero and one. $P_{i t}$ in our model is a non-linear function related to $X_{i t}^{R} \beta$. If the probability of a company to be a dividend payer is $P_{i t}$ the likelihood of non-payer will be (1$\left.P_{i t}\right)$. So,

$$
\begin{gathered}
P_{i t}=\frac{1}{1+\mathrm{e}\left(-X_{i t}^{R} \beta\right)} \\
\text { Thus, } \quad \frac{P_{i t}}{1-P_{i t}}=\frac{1+e\left(X_{i t}^{R} \beta\right)}{1+e\left(-X_{i t}^{R} \beta\right)}=e\left(X_{i t}^{R} \beta\right)
\end{gathered}
$$

where $P_{i t} / 1-P_{i t}$ known as the odds ratio in support of paying dividend calculated as the probability of dividend payer $\left(P_{i t}\right)$ divided by the probability of dividend non-payer $\left(1-P_{i t}\right)$. Refer to "(4)," can be transformed by inserting the natural log on each side,

$$
\ln D I V D U M=\ln \left(\frac{P_{i t}}{1-P_{i t}}\right)=X_{i t}^{R} \beta
$$

Hence, the present study uses the following formula to estimate the Logit regression model:

$$
\ln D I V D U M=X_{i t}^{R} \beta+\epsilon_{i t}
$$

where, (DIVDUM), as mentioned before, is a dummy variable which takes the value of 1 if a company paid the dividend in year ' $t$ ' and zero otherwise. $X_{i t}$ is the column matrix-vector of different independent variables for firm ' $i$ ' in year ' $t$ ' and $\epsilon_{i t}$ the residual error for the company ' $i$ ' in year ' $t$ ' with $N\left(0, \sigma^{2}\right)$.

\section{Measurement of Variables}

To test the impact of corporate governance on dividend payouts two-dividend payout measures viz., dividend payout ratio and dividend dummy variables are used. Following [25], [19] the dividend payout ratio in Tobit model is measured as dividend per share divided by earning per share whereas for Logit model, the dividend dummy variable is used which is set to ' 1 ' if a firm pays dividend in year ' $t$ ' and ' 0 ' otherwise. For both the models, the primary explanatory variables are independent directors (INDDIR) and board size (BS). Independent director refers to the percentage of independent directors on the board [19], [25]. Board size (BS) is measured as the total number of directors on a company's board [5], [26], [27].

The study also uses several firm specific control variables such as profitability, liquidity, assets structure, business risk, firm's size, borrowings, and insiders' ownership that determine the dividend policy of the selected firms. Profitability is measured as the return on asset (ROA), calculated by dividing the net income by total assets. Profitability is expected to have a positive and significant impact on the dividend policy because profitability increases the firm's capacity to pay dividends [2], [17]. To control the 
firm's liquidity, current ratio (CR) has been used which is calculated as current assets divided by current liabilities. A high current ratio indicates financially stability of a firm which may have a capacity to pay higher dividends [19], [28], [29].

The assets structure of a company is controlled by using tangible assets ratio (FTA) which is measured as (total assets-current assets) divided by total assets of a company. Koch, P.D., Shenoy, C., [30] argued that tangible assets structure has a positive relationship with dividend policy while [31], [32] argued that assets tangibility has a negative relationship with the dividend payout policy.

Further, to control for the firm-specific business risk, beta $(\beta)$ is employed. Most of the previous studies such as [33] have argued that $\beta$ has an adverse impact on the dividend policy because as the risk of a firm increases the chance of being bankruptcy also increases, so the firms pay fewer dividends and keep more retained earnings to face any uncertainty.

Similarly, firm size (SIZE) is employed by taking the logarithm of total assets along with market to book ratio (MTBV) measured by dividing the market price per share by book price per share to control the firm's maturity. Finally, borrowing ratio measured as total debt to total assets (BORR) is used to see the impact of leverage on the probability of dividend payment. More debt may put more pressure on the management for monitoring in which case dividend payment may not be necessary to control agency cost. Therefore, a negative impact of borrowings on the dividend is projected.
Another curial internal factor is insider's shareholding (ISH) representing the shareholding of the insiders of a company i.e., only CEO and executives shareholdings in the company are employed as control variables.

\section{RESULTS AND DISCUSSION}

Table I presents the descriptive statistics of the selected variables used in the regression analysis. It is found that the average dividend payout ratio is $23 \%$ of the EPS with a maximum of $700 \%$ of EPS. The average outside independent director of the board is found to be seven, with a highest of 14 found in case of Bharati Airtel Ltd. for the year 2012. The mean board size is found to be about 10 which vary between 3 to 20 among the selected firms.

The average ROA is $8 \%$ ranging from a lowest $-88.54 \%$ to a highest of $61.70 \%$, showing the variability among the selected firms. It is also evident from Table I that the selected firms are facing liquidity problems, as their CR average is found to be less than two times of current liability indicating that they may find it difficult to meet their short-term obligations. The selected firms borrowed around $24 \%$ of total assets from the market showing their dependency on the debt market. Table I also shows that the insiders hold about nearly $9.5 \%$ of total shares outstanding, which looks reasonable control of ownership. However, they may be in a position of influencing dividend decisions of the selected firms.

TABLE I: DESCRIPTIVE STATISTICS

\begin{tabular}{|l|l|l|l|l|l|l|l|l|l|}
\hline STATS & N & MEAN & SD & SE(MEAN) & SKEWNESS & P50 & MIN & MAX \\
\hline DPR & 1219 & 0.234 & 0.566 & 0.016 & -1.659 & 0.198 & -8.571 & 7.143 \\
\hline INDDIR & 1215 & 6.833 & 2.296 & 0.066 & 0.352 & 7.000 & 0.000 & 14.000 \\
\hline BS & 1219 & 9.548 & 2.744 & 0.079 & 0.543 & 9.000 & 3.000 & 20.000 \\
\hline ROA & 1197 & 7.817 & 9.100 & 0.263 & -0.622 & 6.275 & -88.548 & 61.707 \\
\hline CR & 1215 & 1.800 & 1.653 & 0.047 & 4.885 & 1.405 & 0.126 & 18.239 \\
\hline SIZE & 1219 & 10.830 & 1.535 & 0.044 & 0.541 & 10.653 & 6.753 & 15.618 \\
\hline$\beta$ & 1180 & 1.371 & 7.500 & 0.218 & -5.438 & 1.449 & -115.699 & 32.300 \\
\hline BORR & 1219 & 23.540 & 19.559 & 0.560 & 0.461 & 22.100 & 0.000 & 81.959 \\
\hline MTBV & 1214 & 4.137 & 7.560 & 0.217 & 4.170 & 2.373 & -72.281 & 116.706 \\
\hline ISH & 1209 & 9.425 & 16.696 & 0.480 & 2.167 & 0.881 & 0.000 & 79.061 \\
\hline
\end{tabular}

TABLE II: CORRELATION MATRIX

\begin{tabular}{|l|l|l|l|l|l|l|l|l|l|l|l|}
\hline & DPR & INDDIR & BS & ROA & FTA & CR & SIZE & $\beta$ & BORR & MTBV & ISH \\
\hline DPR & 1.00 & & & & & & & & & & \\
\hline INDDIR & 0.009 & 1.00 & & & & & & & & & \\
\hline BS & 0.041 & $0.69^{*}$ & 1.00 & & & & & & & & \\
\hline ROA & $0.11^{*}$ & 0.014 & 0.047 & 1.00 & & & & & & & \\
\hline FTA & -0.03 & $0.07^{*}$ & $0.10^{*}$ & $-0.14^{*}$ & 1.00 & & & & & & \\
\hline CR & 0.03 & -0.023 & -0.056 & $0.28^{*}$ & $-0.10^{*}$ & 1.00 & & & & & \\
\hline SIZE & 0.02 & $0.31^{*}$ & $0.40^{*}$ & $-0.20^{*}$ & $0.08^{*}$ & $-0.20^{*}$ & 1.000 & & & & \\
\hline$\beta$ & -0.01 & -0.03 & -0.012 & $-0.11^{*}$ & 0.015 & -0.006 & -0.054 & 1.000 & & & \\
\hline BORR & $-0.09^{*}$ & $0.07^{*}$ & $0.10^{*}$ & $-0.58^{*}$ & $0.30^{*}$ & $-0.41^{*}$ & $0.33^{*}$ & $0.07^{*}$ & 1.000 & & \\
\hline MTBV & 0.051 & -0.01 & -0.027 & $0.28^{*}$ & $-0.09^{*}$ & $0.117^{*}$ & $-0.17^{*}$ & -0.04 & $-0.24^{*}$ & 1.000 & \\
\hline ISH & 0.020 & $-0.16^{*}$ & $-0.09^{*}$ & $0.11^{*}$ & -0.055 & $-0.05^{*}$ & $-0.16^{*}$ & 0.012 & -0.001 & -0.001 & \\
\hline
\end{tabular}

Table II shows the Pearson's correlation matrix, which measures the nature and degree of relationship among the selected variables employed in the study. The correlations between the variables are low to moderate, which proves the absence of multicolinearity among the selected variables. The correlation coefficients of the selected variables vary from -0.009 to 0.69 which falls within an acceptable range. However, the size of the board and percentage of non-executive directors is found to have the highest correlation in the correlation matrix.

The Tobit and Logit regression results are reported in Table III and IV respectively. It can be observed from Table 
III, the estimated value of rho score (a measure overall model

fit) is about 0.185 indicating a satisfactory explanatory power

of the selected independent variables.

TABLE III: DETERMINANTS OF DIVIDENDS: ESTIMATES FROM TOBIT MODEL

\begin{tabular}{|c|c|c|c|c|c|c|}
\hline \multirow{2}{*}{$\begin{array}{l}\text { Independent } \\
\text { Variables }\end{array}$} & \multirow[b]{2}{*}{ Coefficient } & \multirow[b]{2}{*}{ SE } & \multirow[b]{2}{*}{$z$} & \multirow[b]{2}{*}{$P>z$} & \multicolumn{2}{|c|}{ 95\% Confidence Interval } \\
\hline & & & & & Lower Limit & Upper limit \\
\hline INDDIR & $-0.029 * *$ & 0.013 & -2.170 & 0.030 & -0.055 & -0.003 \\
\hline BS & $0.029 * *$ & 0.012 & 2.470 & 0.014 & 0.006 & 0.052 \\
\hline ROA & $0.009 *$ & 0.003 & 3.530 & 0.000 & 0.004 & 0.014 \\
\hline CR & -0.016 & 0.013 & -1.290 & 0.197 & -0.041 & 0.008 \\
\hline FTA & 0.090 & 0.0979 & 0.92 & 0.356 & -0.101 & 0.282 \\
\hline SIZE & $0.025 * * *$ & 0.014 & 1.770 & 0.077 & -0.003 & 0.053 \\
\hline$\beta$ & $0.004 * * *$ & 0.002 & 1.930 & 0.054 & 0.000 & 0.007 \\
\hline MTBV & 0.000 & 0.003 & 0.140 & 0.887 & -0.005 & 0.006 \\
\hline BORR & $-0.003 * *$ & 0.001 & -2.080 & 0.037 & -0.005 & 0.000 \\
\hline ISH & 0.001 & 0.001 & 0.490 & 0.624 & -0.002 & 0.003 \\
\hline Constant & -0.141 & 0.149 & -0.940 & 0.345 & -0.433 & 0.151 \\
\hline Sigma_U & 0.210 & 0.023 & 9.160 & 0.000 & 0.165 & 0.255 \\
\hline Sigma & 0.441 & 0.012 & 38.270 & 0.000 & 0.419 & 0.464 \\
\hline Rho & 0.185 & 0.036 & & & 0.123 & 0.263 \\
\hline
\end{tabular}

Notes: 1. The dependent variable is dividend payout ratio. 2. Number of observations $=1158 ;$ Censored observations $=181$ and uncensored observations $=977$. 3. Log Likelihood $=-792.091 ;$ Wald Chi ${ }^{2}(9)=43.990 ;$ Porb $>$ chi $^{2}=0.000 .4 . *, * * * *$ indicate significance level at $1 \%$, $5 \%$ and $10 \%$ level of significance respectively.

TABLE IV: DETERMINANTS OF DIVIDENDS: ESTIMATES FROM LOGIT MODEL

\begin{tabular}{|c|c|c|c|c|c|c|}
\hline \multirow{2}{*}{$\begin{array}{l}\text { Independent } \\
\text { Variables }\end{array}$} & \multirow[b]{2}{*}{ Coefficient } & \multirow[b]{2}{*}{ Std. Err. } & \multirow[b]{2}{*}{$z$} & \multirow[b]{2}{*}{$P>z$} & \multicolumn{2}{|c|}{$95 \%$ Confidence Interval } \\
\hline & & & & & Lower Limit & Upper limit \\
\hline INDDIR & $-0.687 * *$ & 0.306 & -2.250 & 0.025 & -1.286 & -0.088 \\
\hline BS & $1.067 *$ & 0.316 & 3.380 & 0.001 & 0.448 & 1.685 \\
\hline $\mathrm{ROA}$ & $0.068 * * *$ & 0.037 & 1.840 & 0.065 & -0.004 & 0.141 \\
\hline CR & -0.192 & 0.193 & -0.990 & 0.322 & -0.571 & 0.187 \\
\hline FTA & 1.8138 & 1.787 & 1.01 & 0.310 & -1.689 & 5.317 \\
\hline SIZE & $0.654 * *$ & 0.324 & 2.020 & 0.043 & 0.020 & 1.288 \\
\hline$\beta$ & -0.021 & 0.041 & -0.530 & 0.597 & -0.101 & 0.058 \\
\hline MTBV & 0.021 & 0.031 & 0.660 & 0.509 & -0.040 & 0.081 \\
\hline BORR & $-0.051 * *$ & 0.023 & -2.190 & 0.028 & -0.096 & -0.005 \\
\hline ISH & 0.034 & 0.027 & 1.280 & 0.201 & -0.018 & 0.086 \\
\hline Constant & -4.351 & 3.253 & -1.340 & 0.181 & -10.726 & 2.024 \\
\hline /Lnsig2u & 2.991 & 0.218 & & & 2.563 & 3.419 \\
\hline Sigma_U & 4.461 & 0.487 & & & 3.602 & 5.526 \\
\hline Rho & 0.858 & 0.027 & & & 0.798 & 0.903 \\
\hline
\end{tabular}

Notes: 1. The dependent variable is dividend dummy (DIVDUM). 2. Number of observation=1147. 3. Log Likelihood = -174.400; Wald = 25.570; Porb $>\operatorname{chi}^{2}=0.002 .4 . *, * * * * *$ indicate significance level at $1 \%, 5 \%$ and $10 \%$ level of significance respectively.

The two primary independent variables of Tobit model viz., INDDIR and BS have the expected sign and are significant. For instance, the coefficient value of INDDIR is negative and found to be significant $(Z=-2.170, p<.05)$, whereas the coefficient value of BS is positive and found to be significant $(Z=2.470, p<.05)$. Consistent with Tobit model, Logit model (Table IV) also produces similar evidence. The results indicate that when the numbers of independent directors increase, the dividend payment to the shareholders goes down. This may happen because the independent directors tend to protect the interests of minority shareholders that mitigate the agency problem. Therefore, firms may not use dividend payment as a tool to reduce the agency problem. Thus, with the inclusion of more number of independent directors on the board of the company may mitigate the conflicts between the agent and principal. Hence, the results support that firms might use corporate governance and dividend policy as a substitute for each other.

Profitability (ROA) of firms is found to be positive and significant $(Z=3.53, p<0.01)$ in the both the estimated models indicating that profitable firms are more likely to pay dividends than the unprofitable firms. Therefore, the probability of being a dividend payer is more if the firm has higher profitability ratio.

Similarly, the selected variables like the firm size also shows a significant and positive relationship with dividend payout ratio of the selected firms indicating that as the firms average total assets increase the payment of dividends will also increase. Fixed assets structure has a positive relationship but is found to be insignificant in both the estimated models. Further, the Tobit and Logit model also show that there exists an insignificant and negative correlation between the liquidity and dividend payout of the selected firms indicating more the payment of dividend leads to less liquidity.

\section{CONCLUSION AND POLICY IMPLICATION}

The present study applied both panel Tobit and Logit model to find the relationship between corporate governance and dividend payout ratio of 360 non-financial and non-utility companies listed in BSE 500 index during 2012-2016. The study also used other control variables (like firm size, profitability, liquidity, assets structure, firm's risk, leverage, and insider shareholdings). From the estimated models, it is found that for the corporate governance variables used in the study viz., independent directors and board size have significant positive and negative relationship respectively with the dividend payout ratio of the selected firms. The other control variables also have the expected 
desired influence on the dividend payout ratio in both the estimated models. Therefore, it is concluded that dividends could be a substitute for corporate governance for monitoring the agency problem, which has a necessary policy implication for the firms. For example, to mitigate the agency problem the firms can have directors that are more independent on its board, which may reduce the need of paying dividends. Thus, the firms operating in emerging economy like India can try to increase the corporate governance practices by expanding the role of independent directors and encourage more participation in board meetings, which can reduce agency cost.

\section{ACKNOWLEDGMENT}

The authors would like to appreciate the anonymous reviewers for their constructive comments.

\section{REFERENCES}

[1] J. Lintner, "Distribution of incomes of corporations among dividends, retained earnings, and taxes," The American Economic Review, vol. 46, no. 2 , pp. $97-113,1956$.

[2] V. Sharma, "Independent directors and the propensity to pay dividends," Journal of Corporate Finance, vol. 17, no. 4, pp. 1001-1015, 2011.

[3] T. Mitton, "Corporate governance and dividend policy in emerging markets," Emerging Markets Review, vol. 5, no. 4, pp. 409-426, 2004

[4] F. H. Easterbrook, "Two agency-cost explanations of dividends," The American Economic Review, vol. 74, no. 4, pp. 650-659, 1984.

[5] C. Ghosh, and L. Sun, "Agency Cost, Dividend Policy and Growth: The Special Case of REITs," Journal of Real Estate Finance and Economics, vol. 48, no 4, pp. 660-708, 2014.

[6] A. Hu, and P. Kumar, "Managerial entrenchment and payout policy," The Journal of Financial and Quantitative Analysis, vol. 39, no. 4, pp. 759-790, 2004.

[7] L. F. White, "Executive compensation and dividend policy," Journal of Corporate Finance, vol. 2, no. 4, pp. 335-358, 1996.

[8] J. Farinha "Dividend policy, corporate governance and the managerial entrenchment hypothesis: an empirical analysis," Journal of Business Finance and Accounting, vol. 30, no. 9, pp. 1173-1209, 2003.

[9] S. A. Zahra, and J. A. Pearce, "Boards of directors and corporate financial performance: A review and integrative model," Journal of Management, vol. 15, no. 2, pp. 291-334, 1989.

[10] E. Mansourinia, M. Emamgholipour, E. A. Rekabdarkolaei, and M. Hozoori, "The effect of board size, board independence and CEO duality on dividend policy of companies: Evidence from tehran stock exchange," International Journal of Economy, Management and Social Sciences, vol. 2, no. 6, pp. 237-241, 2013.

[11] M. Shehu, "Board characteristics and dividend payout : Evidence from Malaysian public listed companies," Research Journal of Finance and Accounting, vol. 6, no. 16, pp. 35-40, 2015.

[12] A. Ajanthan, "Corporate governance and dividend ratio: A study of listed hotels and restaurant companies in Sri Lanka," International Journal of Management, IT and Engineering, vol. 26, no. 3, pp. 98-114, 2013.

[13] O. Abdelsalam, A. El-Masry, and S. Elsegini, "Board composition, ownership structure, and dividend policies in an emerging market." Managerial Finance, vol. 34, no. 12, pp. 953-964, 2008.

[14] J. Abor and V. Fiador, "Does corporate governance explain dividend policy in Sub-Saharan Africa?" International Journal of Law and Management, vol. 55, no. 3, pp. 201-225, 2013.

[15] M. Afzal and S. Sehrish, "Ownership structure, board composition and dividend policy in Pakistan," African Journal of Business Management, vol. 7, no. 11, pp. 811-817, 2011.

[16] K. Gugler, "Corporate governance, dividend payout policy, and the interrelation between dividends, R\&D, and capital investment," Journal of Banking and Finance, vol. 27, no. 7, pp. 1297-1321, 2003.

[17] F. Adjaoud and W. Ben-Amar, "Corporate governance and dividend policy: Shareholders' protection or expropriation?" Journal of Business Finance and Accounting, vol. 37, no. 5/6, pp. 648-667, 2010.
[18] M. C. Jensen and W. H. Meckling, “ Theory of the firm: Managerial behavior, agency costs and ownership structure," Journal of Financial Econo.mics, vol. 3, no. 4, pp. 305-360, 1976.

[19] S. Byoun, K. Chang, and Y. S. Kim, "Does corporate board diversity affect corporate payout policy?" Asia-Pacific Journal of Financial Studies, vol. 45, no. 1, pp. 48-101, 2016.

[20] S. A. Zahra and J. A. Pearce, "Boards of directors and corporate financial performance: A review and integrative model," Journal of Management, vol. 15, no. 2, pp. 291-334, 1989.

[21] G. C. Kiel and G. J. Nicholson, "Board composition and corporate performance: How the Australian experience informs contrasting theories of corporate governance," Corporate Governance An International Review, vol. 11, no. 3, pp. 189-205, 2003.

[22] R. Haniffa, and M. Hudaib, "Corporate governance structure and performance of Malaysian listed companies," Journal of Business Finance and Accounting, vol. 33, no. 8, pp. 1034-1062, 2006.

[23] M. J. Conyon and S. I. Peck, "Board size and corporate performance: evidence from European countries," The European Journal of Finance, vol. 4, no. 3, pp. 291-304, 1998.

[24] I. Bolbol, "Board characteristics and dividend payout of Malaysian companies," Unpublished Master Dissertation, Universiti Utara Malaysia, pp. 1-30, June 2012.

[25] B. Al-Najjar, and K. Hussainey, "The association between dividend payout and outside directorships," Journal of Applied Accounting Research, vol. 10, no. 1, pp. 4-19, 2009.

[26] A. Roy, "Dividend policy, ownership structure and corporate governance: An empirical analysis of Indian firms," Indian Journal of Corporate Governance, vol. 8, no. 1, pp. 1-33, 2015.

[27] J. Chen, W. S. Leung, and M. Goergen, "The impact of board gender composition on dividend payouts," Journal of Corporate Finance, vol 43(October), pp. 86-105, 2017.

[28] T. G. Coville and G. Kleinman, "Independent directors and dividend payouts in the post sarbanes-oxley era," Sustainability and Governance, Emerald Group Publishing Limited, pp. 57-98, 2015.

[29] H. DeAngelo, L. DeAngelo, and D. J. Skinner, "Corporate payout policy," Foundations and Trends in Finance, vol. 3, no. 2/3, pp. 95-287, 2009.

[30] P.D. Koch and C. Shenoy, "The information content of dividend and capital structure policies," Financial Management, vol. 28, no. 4, pp.16-35, 1990.

[31] V. Aivazian, L. Booth, and Cleary, "Do emerging market firms follow different dividend policies from U.S. Firms?" The Journal of Financial Research, vol. 26, no. 3, pp. 371-387, 2003.

[32] C. K. Ho, "Corporate governance and corporate competitiveness: An international analysis," Corporate Governance and Corporate Competitiveness, vol. 13, no. 2, pp. 211-225, 2005.

[33] P. R. Chang and S. G. Rhee, "The impact of personal taxes on corporate dividend policy and capital structure decisions," Financial Management, vol. 19, no. 2, pp. 21-31, 2009.

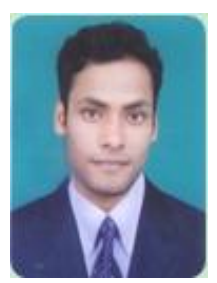

Debasis Pahi was born at Odisha, India in May 1990 $\mathrm{He}$ is a Ph.D scholar of financial economics in the Department of Humanities and Social Sciences, Indian Institute of Technology Kharagpur, India. He holds masters and M.Phil. degree in commerce from Utkal University. His research interest includes corporate finance and governance, accounting education and international finance. He has also presented his research work in several national and international conferences. $\mathrm{He}$ is a life member of All Indian Accounting Association, All India Commerce Association.

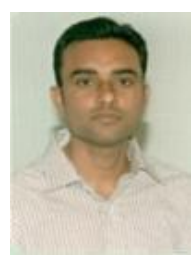

Inder Sekhar Yadav is presently serving as an assistant professor at the Indian Institute of Technology Kharagpur and holds a masters, M.Phil., Ph.D. degree in Economics from University of Hyderabad. He has over 8 years of experience in academia. At the institute, he is involved in teaching, research, consultancy, and training. His teaching and research interests include financial economics; industrial economics and enterprise risk management. He has published several articles in reputed national and international journals. He has also presented his research work in several national and international conferences. He is recipient of Prof. M. J. Manohar Rao Young Economist Award-2013 awarded by The Indian Econometric Society. 